\title{
A CRISE DO ESTADO DE DIREITO E
}

A NOVA CONSTITUIÇÃO DO BRASIL

THE RULE OF LAW CRISIS AND THE BRAZILIAN NEW CONSTITUTION

\section{A B. Cotrim Neto}

Professor da Faculdade de Direito da Universidade do Rio de Janeiro

\section{SUMÁRIO}

Antecedentes históricos. As Constituições dos séculos XVIII e XIX. A realização do Estado de direito. Instituição e política. Direito e poder. Agonia do Estado representativo parlamentar. A doutrina Italiana e Alemã. O Estado social. A Constituição francesa de 1958. A Constituição do Brasil de 1967. O processo legislativo. Conclusão.

1. No Brasil encontra-se em fôrça - para usarmos expressão anglo-germânica (in force ou in Kraft) adequada - desde 15 de março de 1967, uma nova Constituição federal. Ela é a 5. a da República, e 7. que teve nosso país, considerada a que Pedro I outorgou em 1824, e a que D. João VI se viu compelido a adotar em 1821, pela ação dos liberais indígenas (a Constituição espanhola de 1812, elaborada pelas rumorosas Côrtes do Cadiz), adoção simbólica, uma vez que o diploma jamais teve vigência entre nós.

O fato, em si, não teria significação maior: ainda que de hierarquia e amplitude excelsas, a Constituição não passa, afinal, de uma lei, da qual - pelas práticas contemporâneas se pode inferir - nem é mesmo possível dizer-se 
que haja de ter duração superior à dos diplomas normativadores ordinários. Atendo-nos, simplesmente, ao verificado no Brasil, podemos observar que, enquanto nosso Código Civil (de 1916) vigora há mais de 50 anos, nesse período a nação assistiu à reforma da Constituição de 1891 (em 1926) e à edição de quatro diversas Constituições (em 16 de julho de 1934; em 10 de novembro de 1937; em 18 de outubro de 1946, e, por fim, agora em 1967)...

O que importa em uma nova Constituição é a tentativa, nela inscrita, de colocar a realidade institucional de um povo em novos planos ideais. Uma Constituição é sobretudo um programa de ação, ademais de ser uma estratificação jurídica da realidade institucional.

A história confirma êste asserto, e o pensamento dos publicistas coetâneos o reafirma.

Escreveu o eminente romancista J. Ortolan (In: Histoire de la Législation Romaine, Paris, 11. a ed., 1880, p. 275) que a palavra "Constituição" deriva da locução geral jus constituere, empregado não sòmente para as leis, como para os plebiscitos, para os senatusconsultos, e, mesmo para as obras dos jurisconsultos. Entretanto, decaída a República, instituído o imperium do Príncipe, o nome genérico aplicado a todos êsses atos emanados de fontes as mais diversas, passou a designar os atos derivados dessa fonte única, que se tornaria a única geratriz do direito: foram as constitutiones principum, a mais antiga das quais atribuem, uns, ao imperador Adriano, mas outros fazem remontar a Augusto, no limiar da Era Cristã. Para o citado Ortolan, essas "Constituições" variavam de feitio e de destinação: umas eram gerais, aplicando-se a todo mundo; outras eram particulares, decidindo certos casos submetidos ao julgamento do soberano, ou regendo situações e procedimentos de pessoas às quais se destinavam.

Afinal, em decorrência de velha prática, que assentava priscos fundamentos na Lex Regia do início da vida de Roma, essas "Constituições" significavam manifestação da vontade do Imperador, do Princeps, misto de divindade e de legislador essencial: "Quod Principi placuit, legis habet vigorem".

2. Após a desagregação do Império Romano, o vocábulo em questão persistiu - durante a Idade Média - para designar regras monacais, eclipsando-se, em seguida, e reaparecendo no século XVIII, sob a influência dos filósofos. Segundo Maurice Duverger (In: Instituciones Politicas y Derecho Constitucional, trad. esp., ed. Ariel, 1962, p. 2), para êsses, "Constituição" significaria, antes de tudo, a idéia de organização, num sentido de estruturação racional. Escreve o professor da Faculdade de Direito de Paris que, quando Turgot, certa feita, disse a Luiz XIV — "Sire, vosso reino carece de Constituição", queria exprimir 
que a França carecia de instituições políticas coordenadas, organizadas, numa expressão ìntimamente relacionada com o racionalismo da época.

Na segunda metade dêsse século XVIII, com a divulgação e aceitação das idéias do Contrato Social de Rousseau, a palavra "Constituição" deixou de ter sentidoneutro: tornou-se, por um fenômeno de valoraçãoideológica, implicante de tomada de posição política de oposição ao absolutismo dos monarcas; deixou de exprimir apenas a organização racional dos podêres públicos, consagrada em texto escrito, e passou a significar, também, um conteúdo liberal. $\mathrm{O}$ artigo 16 da Declaração dos Direitos do Homem, proclamada durante a Revolução Francesa, em 1789, foi vasado neste pensamento, ao dizer: "Tôda Sociedade na qual a garantia dos Direitos não esteja assegurada, nem a separação dos podêres determinada, não tem Constituição". Ainda o professor Duverger, por isso, escreveu que as Constituições elaboradas durante o período final do século XVIII corresponderiam a um suposto pacto social fundamental, sendo vistos os seus textos escritos como superiores às leis e aos regulamentos, e considerados a garantia das liberdades dos indivíduos dentro da sociedade consentida (ob. cit., p. 224).

De tal forma se verificou a identificação do nome "Constituição" com o significado de diploma liberal que os monarcas absolutos - quando compelidos a aceder na exigência de um diploma escrito básico, por parte de seus súditos - usaram de vocábulos particulares, chamando "Carta" à Constituição, e "outorga" ao ato de sua promulgação: destarte, êles agiam como os soberanos da Idade Média, que outorgavam Cartas de autonomia aos burgos de cujo apoio necessitavam, na luta contra os senhores feudais, num ato em que procediam como entidades autorizadas por um direito divino (cfr. Duverger, ob. cit., p. 226, e Hans Kelsen, Allgemeine Staatslehre, Berlim, ed. Springer 1925, p. 338). Parece-nos que a primeira das Constituições dêsse tipo haverá sido a que Luiz XVIII emitiu, retornando à França após a primeira abdicação de Napoleão, em 1814: "La Charte" - escreveu Georges Burdeau (In: Droit Constitutionnel et Institutions Politiques, Paris, L.G.D.J., 1965, p. 282) - "cujo nome marca, mesmo, a intenção de romper com a tradição revolucionária, é então concedida pelo rei a seus súditos; por via dela, o rei voluntàriamente limita o poder, decorrente de sua posição na dinastia real, e não da soberania popular (...), contrapartida de outorga é a concessão feita ao espírito nôvo".

No Brasil, tivemos um Diploma Fundamental que vigorou por todo o período imperial, desde 1824, em virtude de "outorga" de D. Pedro I. Êste, entretanto, preferiu chamá-lo de "Constituição", como o fêz no preâmbulo do instrumento. 
3. Saliente-se, no entanto, que o fetichismo da Constituição desenvolveu-se, também, nos meados do século XIX, em virtude do surgimento de uma nova ideação: o Estado de Direito.

O maior interêsse dos liberais da centúria precedente residira na elaboração de diplomas escritos, onde se consagraria de modo categórico a divisão dos podêres do Estado, com o que - imaginava-se - seria possível contrarrestar a prepotência dos soberanos absolutos; a Revolução Francesa e as suas constituições, como as leis que organizaram os podêres do regime nôvo, especialmente as que lhes traçaram os limites, sob fundamento de garantir a independência de cada um, coartou a ação da Justiça no contrôle da execução da lei. Apesar da proliferação dos diplomas constitucionais, os direitos dos cidadãos - e em nome dêles se fizera a Revolução do século XVIII - continuavam postergados. O "Estado de Direito" viria então para assegurar aquilo a que os autores alemães, que o engendraram, denominariam de Gesetzmässigkeit, no sentido mais amplo, isto é, a legalidade, a conformação com as prescrições da lei, das ações do Govêrno, do Executivo, ainda detentor residual do despotismo perempto dos Príncipes.

A Constituição seria, então, o instrumento idôneo e eficiente para a realização do Estado de Direito.

É certo que nem sempre se considerou uma lei fundamental rígida como o símbolo completo dêsse Estado de Direito, pois, às vêzes, se preferia simbolizá-lo no fortalecimento do Juiz para o contrôle do Executivo: mas, ainda os que assim pensaram, como Otto Bähr (cuja obra Der Rechtsstaat, ed. em 1864, e em 1961, reeditada, por processo foto-mecânico, pela Scientia Aalen, foi das primeiras especialmente dedicadas ao tema), admitiam as Constituições como um valioso instrumento para codificação do Direito Público, no mais amplo sentido (ob. cit., p. 48).

Ultrapassada a fase romântica do constitucionalismo dos fins do século XVIII, e, especialmente, do século XIX, verificou-se que as Constituições, Cartas, - ou que outro nome tivessem - não seriam suficientes, por si sós, para bastar à vida de um povo. Mais fortes que os documentos, escritos e solenemente jurados ou promulgados, revelaram-se os fatos da vida social, os fatôres psicológicos que suportam, justificam e explicam as Constituições. Como exprimiu o eminente Burdeau - com tôda a autoridade que repousa em sua imensa bagagem, contida principalmente no Traité de Science Politique - as raízes dêsses diplomas jurídicos devem mergulhar na história e na sociologia, nos dados da filosofia e, até nas lições das experiências pessoais vividas; e, se os mecanismos constitucionais comandam todo o nosso destino, 
de perto ou de longe, na sua utilização ou seu funcionamento, êles sofrem, em revanche, a emprêsa de nossos atos e de nossos pensamentos.

Portanto, chegou-se hoje ao entendimento de que as Constituições só serão válidas quando corresponderem às instituições políticas consagradas, quando atenderem ao acervo de experiências sociais ou puderem alicerçar novas instituições políticas viáveis.

4. Mas, o que se deve entender como "instituição política", ou simplesmente como "instituição" e "política", se nós consideramos que a Constituição de um país enforma o objeto principal do Direito Constitucional, mas não é dêle - fato notório - objeto exclusivo?

Nenhum dos dois vocábulos supra indicados - "instituição" e "política" - tem um sentido preciso.

Se tomarmos o verbete "instituição" da Enciclopédia de Cultura (Rio, ed. F. Bastos, 1955, p. 187) do saudoso professor Joaquim Pimenta, nós teremos êsses registros que sumariamos: para Hauriou a instituição é uma organização social constituída de indivíduos, que tem existência própria e independente dos mesmos indivíduos, os quais podem desaparecer, enquanto ela persistirá; para J. M. Baldwin, a instituição é a forma permanente na qual se encarna a organização dos membros de um grupo, para o cumprimento de uma função social (p. ex., a Escola, a Igreja, o Estado), sendo, ainda, órgão da vida social, que serve aos indivíduos mas dêles não depende.

Por sua vez, Maurice Duverger, que também se ocupa do estudo em causa, após repassar uma série de manifestações - inclusive a de Durkheim - prefere reservar o têrmo "instituição" à designação de um conjunto de idéias, de crenças, de usos, constitutivos de um todo orgânico e coordenado (p. ex., o matrimônio, a família, a propriedade, as eleições, o govêrno...), o que não se choca fundamentalmente com os elementos do verbete de Pimenta, embora êsse seja incompleto, com referência à menção do pensamento de Hauriou (para quem é mister, ademais, que a "instituição", para ser tal, se realize e dure jurìdicamente, num meio social - v. Duverger, ob. cit., p. 6).

Quanto ao vocábulo "política", no verbete próprio da obra de Joaquim Pimenta (p. 284), nós encontramos essa observação: em linguagem corrente, êle se refere a sistema, ou forma de govêrno, ou, ainda, à arte de governar; mas êle se refere, igualmente, à atividade de grupos ou partidos que disputam ou participam do poder, e, por último, a fatos ou acontecimentos tidos por decisivos, na história de um povo, ou de evidente relêvo nos negócios do Estado. Mas, Pimenta, igualmente, nota que, sob o ponto de vista científico, "política" compreende os fatos e acontecimentos supramencionados, além 
de outros que formam um dos ramos da sociologia (da sociologia política, a qual tem por objeto o estudo da origem do Poder, os processos de formação e evolução dos Estados, dos sistemas de govêrno e da constituição de sua estrutura).

Já o professor Duverger (ob. cit., p. 7) entende que o conceito de "política" se refere a duas ordens diferentes de fenômenos, segundo seja êle encarado pelo ângulo da etimologia do vocábulo, ou pertinente ao fenômeno social fundamental. Na primeira situação, dir-se-á "política" àquilo que corresponde às instituições de certa comunidade humana, do Estado (assim, exemplo do autor citado, se toma o adjetivo na expressão "economia política", que se opõe à economia familiar, doméstica, etc.). Como fenômeno social básico, Duverger indica aquela distinção que Duguit fazia entre governantes e governados, daí tirando o seguinte destaque: em todo agrupamento humano existem duas categorias de pessoas, as que mandam e as que obedecem, as que dão ordens e as que a elas se submetem, os chefes e os membros, em resumo, os governantes e os governados. Semelhante distinção fundamental é encontrada mesmo na família, nos municípios, no Estado, nas associações, nas confrarias, nas igrejas, etc.: destarte, e por isso, chamar-se-á de "política" à instituição (instituição política) que se refere aos governantes e sua autoridade, aos chefes e seus subordinados (eodem loci).

Ainda outra vez, diremos serem essencialmente conciliáveis os conceitos de "política" emitidos nas obras de Pimenta e de Duverger, que poderão ser resumidos nesta idéia: política é a sistematização das relações de poder e dos processos de sua efetivação, na sociedade organizada.

Nessas condições, serão "instituições políticas" aquêles órgãos permanentes ou aquelas entidades éticas, ambos de natureza social, que se realizam e prevalecem jurìdicamente, em têrmos de contribuir para a organização e a segurança da comunidade.

5. Nos séculos anteriores, especialmente no XIX, como vimos, a idéia de Constituição, e, por via de conseqüência, de Direito Constitucional, encerrava uma mensagem política. É conveniente, porém, esclarecer-se que a ela se opunha o pensamento tradicionalista, pretendendo que - em vez das estruturas engendradas pela técnica jurídica - fôssem resguardadas as estruturas sociais e políticas engendradas pela história, pelos costumes: se os liberais queriam uma Constituição, os outros lhes contrapunham as instituições patinadas pelo tempo; às ideações dos liberais, que os tradicionalistas pretendiam artificiais, estes opugnavam com o que era estimado natural. 
Não apresenta nenhum interêsse, contemporâneamente, a divergência de ontem, pois o desenvolvimento dos estudos sociológicos nos fêz compreender que inexiste, ou deve inexistir, incompatibilidade entre o que é de natureza jurídica e o que é de natureza social, embora os dois campos se apresentem perfeitamente delimitados. Opor Instituição, ou Instituição Política, a Constituição não restabelece, hoje, a opção de ontem, mas implica no admitir-se que a segunda só será aceitável quando não contraste fundamentalmente com a primeira. Tão importante é o estudo conjugado dessas matérias que em França, desde 1954, são ambas estudadas numa cadeira única (Direito Constitucional e Instituições Políticas), o que sugeriu a Pablo Lucas Verdú - catedrático de Direito Político na Espanha - que o Direito Constitucional se apresenta agora, em França, como o direito das instituições políticas fundamentais, quiçá como um Direito Institucional (In: Pref. à cit. trad. da obra de Duverger).

Essa nova orientação dos estudos jurídicos pertinentes ao Estado, certamente coincide com anciã inspiração, a que vem de Duguit e da sua escola bordelesa, a qual, rechaçando a idéia alemã do Estado-poder, recomendava estoutra mais humanista do Estado-colaboração, do Estado não-deificado, do Estado desmitificado.

Essa é, também, a posição que adotamos, sem prejuízo de aceitarmos como inelutável - o fortalecimento do Estado contemporâneo (ao contrário de Duguit), que não tememos, desde que preservados certos requisitos de natureza democrática. Nossa atitude, em que pêsem as aparências de contradição, resulta do admitir aqui que Burdeau apontou mais ou menos com êste pensamento: o Estado de hoje se apresenta, universalmente, intervencionista, como o centro da "ordem regulamentar"; a regulamentação estatal nos Estados Unidos, por exemplo, não é, em quantidade, menor que na Rússia, e, num como noutro caso, as mesmas questões solicitam a atenção dos governantes; não se trate, todavia, de colocar o problema do finalismo estatal num enunciado em forma de oposição entre o intervencionismo e o abstencionismo, pretendendo, eventualmente, combater o fato consumado no primeiro. Entretanto, e prosseguimos com Burdeau, onde é possível a defesa da liberdade humana, do súdito ou do cidadão, é na determinação dos fins que motivam a ação do Poder e dos meios que êle pode utilizar; em outros têrmos, não se conteste ao Govêrno o direito de regulamentar tal ou qual domínio de atividade, mas se conceda um espírito à ação do Poder, reconhecendo sua generalidade e sua permanência, e, ainda, por outro lado, fixando o lugar e o papel que se entende reservar ao homem, num mundo onde o Estado se encontra ubíquo. Em resumo, para Burdeau, e nós o seguimos, a estatalidade 
contemporânea deve ser condicionada pelo estabelecimento de uma "ordem regulamentar" (expressão do mestre francês) que respeite o que é devido à ordem natural das sociedades humanas (v. Traité de Science Politique, tomo IV, Paris, L.G.D.J., 1952, p. 143/144).

6. Havemos de convir, porém, que será mais fácil enunciar pensamentos de ordem doutrinária do que conciliá-los com a realidade social contingente. E, portanto, é que nos defrontamos com a perplexidade dos pensadores contemporâneos, diante dos problemas suscitados pela hipertrofia do Estado, inspiradora de uma ordem regulamentar cada dia mais empolgante, e pelo estreitamento da área dos instrumentos de contrôle jurídico da ação do próprio Estado. Em outros têrmos, essa perplexidade decorre da constatação de um fato a que já se convencionou chamar de crise do Estado de Direito, o qual ameaça de aniquilamento àquelas instituições democráticas tão caras à nossa formação ocidental, sem que se tenha à vista uma solução coerente com tal formação e com os nossos estratificados sentimentos de respeito à liberdade e às expansões da personalidade humana.

É semelhante crise do Estado de Direito que tem pôsto em xeque tôdas as Constituições rígidas modernas, gerando uma permanente insatisfação para com seus têrmos, e a sucessão dêsses diplomas cuja duração cada vez mais se reduz (v. nosso estudo sôbre As Constituições Brasileiras e o Espírito das Constituições Contemporâneas, publicado nos Arquivos do Ministério da Justiça, ano XXV, n. 101, 1967); dela é que tem resultado essa estranha floração do que já se chamou de "personalização do poder", que ameaça as instituições políticas de um retôrno àquele despotismo esclarecido, mero consôlo ou tempêro iluminista para o absolute Herrschaft, dos Fredericos e seus pares, do século XVIII; e ela é que tem suscitado essa prevenção do homem, ser social, em relação ao Estado, a ponto de haver autores da categoria de um professor Herbert Krüger (que escreveu a mais importante obra sobre a teoria do Estado, na Alemanha, desde George Jellinek, com sua recentíssima Allgemeine Staatslehre, da ed. Kohlhammer), para quem o Estado chega a ser apresentado como "uma entidade criada pelo homem contra si mesmo".

Vejamos, por exemplo, - a título de ilustração do asserto supra - como essa perplexidade diante da crise do Estado de Direito tem sido encarada, em certos setores do pensamento europeu.

7. É sabido que os italianos sempre tiveram vocação para as excogitações jurídicas no campo do publicismo: a êles se atribui, quiçá a Maquiavel, até o nome "Estado", com a semântica moderna, como a êles ainda, à escola de Ferrara, do século XVIII, se irroga o lançamento da expressão "Direito Constitucional". 
Não surpreende, destarte, que a chocante crise do Estado de Direito esteja ausente das meditações dos juristas ou dos filósofos peninsulares.

Realmente, não faz muito tempo, êsse fato estêve enfàticamente discutido em dois congressos realizados na Itália, um em Roma (de 31 de outubro a 4 de novembro de 1965), outro em Trieste (de 26 a 28 de maio de 1966): no primeiro, que foi o $7 .{ }^{\circ}$ Congresso Nacional de Filosofia do Direito, entre outros, apreciou-se o tema "Direito e Poder", aí destacando-se o contraste entre a concepção liberal clássica, da democracia de Rousseau assentada na soberania popular, e as modernas tendências constitucionais, que levam à imposição de uma efetiva soberania do Estado; no segundo, o I Congresso de Doutrina do Estado, o tema central ainda foi concernente ao deperecimento do Estado Moderno, que o Professor Gianfranco Miglio assinalou, proclamando que "o Estado Moderno (segundo êle, o Estado "representativo-parlamentar") está para morrer e seguramente morrerá, o que é um fato o qual o cientista da política se limita a constatar, eis que o politólogo não faz profecia nem previsões sôbre fatos aleatórios; uma outra forma de Estado substituirá o Estado Moderno. Entretanto, qual possa ser essa forma de regime futuro não cabe ao cientista a função de adivinhar".

Os debates dêsses congressos de Roma e de Trieste, sôbre a matéria de que nos ocupamos, foram resumidos e comentados na Rivista Internazionale di Filosofia Politica e Sociale, dirigida por Lorenzo Caboara (Gênova, ano X, série III, $2 .^{\circ}$ e $3 .^{\circ}$ fascículos, de abril-setembro de 1966), em escritos de Massimo Corsale (p. 251/260) e do próprio Caboara (p. 113/138), sendo que o trabalho dêste último apresentou-se exatamente com o título - A Agonia do Estado Moderno.

Dentre as questões apresentadas no Congresso de Filosofia do Direito, pareceram-nos mais interessantes as colocadas pelo professor Vincenzo Palazzolo, da Universidade de Pisa, que, investindo contra o positivismo jurídico, contra as considerações formalísticas dos problemas do direito, contra o normativismo, destacou a fragilidade do princípio de efetividade que será, em última análise, o calcanhar de Aquiles da construção teórica de Kelsen. Segundo Palazzolo, o que mais interessa é decidir a opção entre a subordinação do Direito ao Poder (objeto da concepção positivística) ou a subordinação do Poder ao Direito (objeto da preocupação jusnaturalística).

Apesar do registro feito, durante os debates, pelo professor torinense Norberto Bobbio, de que Direito e Poder não podem ser entendidos como recìrocamente contrapostos, operante em planos diversos, pois o primeiro é simplesmente a veste formal do segundo, donde ser indiferente a indagação 
de qual deva prevalecer, Palazzolo sustentou seu pensamento contrário ao formalismo jurídico, preconizando o enforcamento sociológico do problema. Partindo, assim, de pressupostos sociológicos, Palazzolo manifestou haver dois "tipos ideais", "duas polaridades" opostas de relação Direito - Poder: Democracia e Ditadura. Contudo, do mesmo jurista o entendimento, Democracia e Ditadura não existem como realidades hipostáticas, como realizações integrais, pois existe maior ou menor aproximação entre uma e outra dessas polaridades, em relação a maior ou menor concentração (Ditadura) ou difusão (Democracia) do Poder.

Temos para nós que a posição do professor Palazzolo é satisfatória, se não como formuladora de um parâmetro utilizável na medição e classificação dos problemas do Estado contemporâneo, ao menos como instrumento eurístico, útil para a colocação de ordem na multiplicidade dos elementos problemáticos e para a valoração intersubjetiva dos mesmos.

No relatório final do Congresso de Roma, não se fixou uma posição pertinente à alternativa entre a concepção liberal clássica e o constitucionalismo contemporâneo, mas se insistiu no problema da difusão do Poder. Por isso, terá ficado sem apreciação conclusiva a controvérsia sustentada pelos professôres Palazzolo e Bobbio, sôbre as duas maneiras de encarar o tema em discussão: para o primeiro, a relação Direito - Poder haveria que se analisar pelo prisma sociológico ou pelo privatístico (aqui, essa relação se efetivaria em têrmos de confronto de "direito subjetivo" com "poder jurídico"); para o segundo, a melhor empostação de uma fenomenologia do Poder e de suas relações com o Direito, na realidade social contemporânea, deveria considerar as diferenças entre a antiga concepção do Poder como "objeto", como coisa a possuir, a conquistar e a perder, e o moderno conceito de Poder como relação entre sujeitos ou grupos de sujeitos, como relação de vontades, em conformidade com o que Croce já tinha apontado na Filosofia della Pratica.

Como quer que se tenha decidido, porém, no Congresso de Filosofia do Direito estêve sempre presente aquilo que não escapa às preocupações dos filósofos, dos juristas, dos sociólogos e dos politólogos coevos, e a que Corsale aponto como "irreversibile deperimento dello Stato di diritto, caposaldo del pensiero politico-giuridico liberale".

No Congresso de Trieste, o tema central dos debates viria a ser, objetivamente, o mesmo que, em Roma, tinha incendido as discussões dos filósofos do Direito, o mesmo que o professor Giorgio Balladore Pallieri, da Universidade Católica de Milão, havia lançado na prefação de 1958 ao seu tratado de Dottrina dello Stato ("Un fatto, a cui stiano attualmente assistendo, 
e che interessa in pari misura il diritto e la politica, é lo sfacelo dello Stato tradizionale"), aquêle que o professor Miglio faria ressoar durante as discussões em tôrno da Doutrina do Estado, no seio da assembléia: “(...) un 'altra forma di Stato sostituirá lo Stato moderno (...)".

Segundo o professor genovês Caboara, unânime - no Congresso - foi o reconhecimento de que reina uma situação de incerteza e um difuso sentimento de desconfiança em relação aos podêres públicos. “Diante da crise que parece envolver as nossas instituições" - proclamou Luigi Zampetti, diretor do Instituto Triestino de Ciências Políticas e organizador do conclave - "êste Congresso representou uma iniciativa destinada à análise, em nível científico, das estruturas fundamentais do Estado"; essa assembléia, conclusão, ainda, de Caboara, foi uma oportunidade para discussão, de maneira orgânica, do problema da reforma do Estado, o que, através da palavra de "estudiosos sérios", envolveu "uma denúncia clara, desinteressada e sem preconceitos, da situação patológica em que manifestamente se encontram as instituições fundamentais sôbre as quais se apóia, e nas quais se articula a estrutura constitucional de nosso Estado" (estudo cit., na Riv., p. 117 e 125).

Prosseguindo em suas considerações, a propósito do Congresso de Doutrina do Estado, Lorenzo Caboara exprime que o Estado de Direito "agoniza", desde que os conceitos de Estado e de Direito não mais se conciliam no plano ético, depois da submersão de tal plano pela economia e pela maré oceânica das exigências, sempre crescentes, da massa: “Se o Direitoéuma formação histórica, a qual nasce e se desenvolve sob a pressão das ocorrências econômicas, só se justifica o seu ser pelo caráter funcional das suas expressões; se o Direito se exprime em normas e institutos que valham, mutáveis no tempo e no espaço, apenas em razão direta de sua idoneidade para a promoção ou a realização das finalidades sociais de natureza econômica, o problema das relações entre o Direito e o Estado, e a própria idéia de Estado de Direito, esmaecem como um sonho; se Direito e Estado são formas ou simples vestimentas com que se cobre uma coletividade (tribal ou nacional, como seja) num determinado momento histórico, êles bem podem ser destruídos (...). O vestuário se consome, porém as necessidades sociais remanescem, e se recobrem de outro modo, de novos sistemas, de uma nova ordem política"' (ob. cit., Riv., p. 134/5).

Esta é, reconhece o professor Caboara, precisamente, a tese sustentada pelos autores marxistas, aprofundada pela escola soviética, e que colabora no processo dissolutivo do Estado, sem resolver-lhe a crise. Não surpreende, por isso, que, dia a dia, aumente o número de instituições e de decretos (sic) que preparam o caminho para um Estado autocrático, planificador, centralizador, totalitário... 
Como proceder-se, então, para que o esmagamento do homem não se verifique, nas engrenagens dêsse Estado moloch? Procurar salvar nosso Estado de Direito agonizante é uma tarefa tão difícil - e Caboara cita "felice immagine di Karl Mannheim" - como procurar substituir as rodas de um trem em movimento... "Come fare?"; "Cosa fare?" - são perguntas que o eminente comentarista do Congresso de Trieste lança, respondendo-se a si mesmo com a recomendação de estudos científicos sérios, a propósito das causas desta crise que está levando para o naufrágio o sistema democrático.

Entretanto, é o próprio Caboara quem exprime dúvidas sôbre a possibilidade de recuperação de nosso "Estado agonizante", quando nas penúltimas linhas de seu trabalho escreveu: "Poderá ser salvo o Estado democrático garantista? Não o sei; e creio que ninguém está em condições de fazer, hoje, uma previsão segura (...)".

Também a Alemanha é notória pela contribuição de seus pensadores à construção do Direito Público, em seguida ao fenecimento medieval das idéias elementares que os romanos chegaram a insinuar nesse ramo. Pode-se afirmar que, ainda no publicismo considerado em seu mais amplo sentido, com a extraordinária eficiência prussiana, foram os alemães os verdadeiros criadores do Direito Administrativo, do mesmo modo que, com os desenvolvimentos do judiciarismo de uma Reichskammergericht imperial, anterior a 1500, e da Fiskustheorie, do século XVIII, seriam os formuladores dos conceitos básicos em que assentaria a doutrina do Estado válida ainda agora. Assim, traçariam êles os lineamentos da teoria da personalidade jurídica do Estado, e, por último - com Otto Bähr e Rudolf Gneist (ambos foram autores de obras editadas sob o mesmo título, Der Rechtsstaat, respectivamente em 1864 e 1872) - elaborariam as fórmulas do Estado de Direito, que tem sido tão caro ao pensamento democrático moderno.

Paradoxalmente, contudo, vêm sendo ainda os alemães os que têm dilapidado a construçãojurídica tãolaboriosamenteerguida pela cultura autóctone: desde Marx, com suas ideações dialéticas, passando pelos Socialistas de Cátedra, e chegando ao romantismo socialista retardatário de Bismarck e ao preconício do Sozialstaat, em que Lorenz von Stein extravazou o melhor de sua notável capacidade, o Estado de Direito é sistemàticamente investido pelos pregoeiros do "Estado Social". Se a revolução comunista de 1917 não foi obra material de alemães, o ideário de seus líderes foi integralmente suprido pelos doutrinadores da Social-Democracia da Alemanha e, em seguida, durante a maior crise enfrentada pelos bolchevistas, estimulado pela República de Weimar. 
Não obstante êsses percalços históricos, o Estado de Direito conseguiu impor-se na própria Alemanha, até que a conjuntura social - a de nossos dias - viesse também, nesse país, a atingi-lo: após o longo interregno apontado por duas derrotas militares (1918/1945), a Alemanha chegou a ter uma Constituição que, pelos padrões clássicos, se poderá classificar de legítimo instrumento de Estado de Direito (os constituintes chamaram de "Lei Fundamental" a êsse diploma, preferindo reservar o título de "Constituição" para a carta de uma nação reunificada).

É certo que a vigente "Lei Fundamental" da República Federal procurou amainar as velhas idéias socializantes do "Estado Social" com as instituições do "Estado de Direito", quando, em seu artigo 20, exprimiu que "A República Federal da Alemanha é um Estado Federal, democrático e social", e, mais enfàticamente, quando determinou aos Estados-membros, no artigo 28, que se organizassem sôbre fundamentos "republicanos, democráticos e de Estados de Direito e Sociais". De que modo, porém, a "Lei" buscou enunciar o "Estado Social" que pretendeu fundir nas instituições de um "Estado de Direito"?... A única coisa encontrada no diploma é o proclama da representação popular mediante eleições, nos órgãos de govêrno, e a divisão dos três podêres, do mesmo artigo $20 . .$.

A realidade jurídica-constitucional dessa república federal, de fato, não permite que se a distinga - reiteramos - das clássicas formulações de Estado de Direito, embora, como soi acontecer nos diplomas modernos, a "Lei Fundamental" encerre elementos de proteção do trabalhador. De qualquer modo, isso não elide a crise contemporânea que devora os regimes de Estado de Direito, pois nada é mais inconciliável com êsses do que a ação imoderadamente intervencionista do Estado coevo.

Com efeito, quem o proclama é um dos mais eminentes constitucionalistas germânicos, o professor Ernst Rudolf Huber, de Göttingen, em obra recente (Nationalstaat und Verfassungsstaat, Stuttgart, ed. Kohlhammer, 1965, p. 267): “O Estado de Direito e o Estado Social são distintos por suas origens: o primeiro emergiu das lutas da burguesia contra o Estado e o segundo de lutas que a sociedade industrial fêz desencadear contra o mesmo Estado. O Estado de Direito visa à proteção da vida, da liberdade e da propriedade do indivíduo; o Estado Social objetiva a segurança de existência, do pleno-emprêgo e da fôrça do trabalho das camadas sociais socialmente menos suficientes. Dêsses contrastes resulta que, enquanto o Estado de Direito visa a proporcionar a garantia de certos direitos inerentes à liberdade e à propriedade, pela redução de seus podêres intervencionistas, o Estado Social, ao contrário, tem 
fortalecida sua intervenção no concernente à liberdade e à propriedade, tanto quanto se faça necessária para a garantia da existência, do pleno-emprêgo e da subsistência da fôrça de trabalho".

O professor Huber, portanto, é quem exprime as posições antagônicas em que residem o Estado de Direito e o Estado Social: um, fundamentalmente abstencionista; outro, essencialmente intervencionista.

O tipo tradicional do Estado de Direito foi o Estado Liberal Burguês, que dominou especialmente até 1914: será possível uma acomodação das instituições dessa época com as que o constitucionalista aponta para o Estado Social, êste mesmo Estado Social que a Grund Gesetz alemã de 1949 manda estabelecer-se em contubérnio com aquêle regime abstencionista?

Vejamos o esquema traçado por Huber para o Estado Social: "A assistência social, a previdência social e a harmonia social são tentativas para corrigir a desintegração da sociedade industrial. Porém todos os empenhos seriam inúteis, se elas apenas visassem contornar a revolução social, em vez de agir sôbre o fundamento do processo da decomposição. A assistência como a previdência social e a harmonia social são apenas meios do Estado Social. Porém, sentido dêsse Estado Social, em cujo serviço tais meios são postos, é a restauração dos fundamentos de uma vida individual digna de ser vivida no seio do mundo industrializado. Isso, entretanto, não significa senão: o sentido da estabilidade social é, concomitantemente, proteção da personalidade, isto é, proteção da individualidade no quadro da sociedade industrial e sob os riscos inerentes à era industrial. Agora nós sabemos, pelas múltiplas experiências dolorosas, que o Estado Social realiza a meta da segurança de uma vida condigna da pessoa apenas quando se cerque de proteção contra o perigo, a êle imanente, da coletivização. Isso é possível, sòmente, quando o Estado Social concretiza a segurança peculiar ao formalismo da estatalidade de Direito, contra as intervenções e os excessos do Estado, porque sem os dispositivos garantidores dessa segurança, como a divisão de podêres, o princípio de legalidade, o princípio de proteção jurídica, assumiria o Estado Social, inevitàvelmente, a fisionomia totalitária do Estado Beneficente (Wohlfahrtsstaat) e do Estado Providência (Versorgungsstaat). " (obra cit. p. 271).

O professor Huber não simpatisa, é óbvio, com o totale Staat, o Estado coletivista, o que reafirma, no prosseguimento dos trechos supratranscritos, todos contidos num capítulo dedicado ao "Estado de Direito e Estado Social, na Moderna Sociedade Industrial": e, por isso, esforça-se em desenvolver a necessidade da conciliação dos dois regimes, com a finalidade de "preservar-se a liberdade pessoal dentro de um sistema de segurança social". 
Contudo, malgrado a eminência de sua cultura, Huber perdeu-se em considerações inexpressivas, ao recomendar formas de conciliação dos dois regimes em questão: segundo o professor do Göttingen, a conciliação é possível e não corresponde a uma associação do inconciliável (Vereinigung des Unvereinbaren), nem a uma harmonização de contrastes (Harmoniesierung der Gegensätze), mas se estriba na conjugação dialética dos elementos do Pessoal e do Social, em busca da unidade, pois, como antes exprimira, se a meta do Estado de Direito reside na proteção da personalidade, essa proteção só se torna eficiente, na sociedade industrial contemporânea, quando alicerçada em segurança social com justiça social...

Como se verifica, essa preconizada "conciliação dialética" que o autor louva, tem a mesma vacuidade que o enunciado da Lei Fundamental alemã, cujos artigos 20 e 28 - acima transcritos no trecho que importa - não foram de mais feliz redação.

Reconheçamos, todavia, que a falta não é do jurista em si, nem dos constituintes alemães: na realidade, é tão forte a crise do Estado contemporâneo, que todos nos sentimos perplexos na busca do remédio salvador.

A razão estava, portanto, com o jurista italiano que nos resumiu a perplexidade de seus colegas reunidos em Congresso de Doutrina do Estado: “(...) poderá ser salvo o Estado democrático garantista?"... “Come fare?"... "Cosa fare?"...

8. Quem se detiver no estudo comparativo da sociedade que ainda vivia, pela metade do século anterior, em lua de mel com a Revolução Industrial, e a sociedade contemporânea, da Era Industrial em sua plenitude, perceberá a extraordinária diversidade de regimes, num e noutro casos. No campo de incidência do direito privado, por exemplo, verificou-se a perda de substância do direito civil, em virtude de múltiplos fatôres, a iniciar pela comercialização do direito privado, que Rippert já salientou há mais de 30 anos, e a chegar à extravagante mas real desintegração de milenares princípios concernentes à propriedade, com a separação entre os podêres do dominus e o contrôle do bem, especialmente no que tange aos bens ou meios de produção; no campo do direito público, verificou-se a demolição das barreiras postas ante o Executivo, que se tornou um poder tão eminente que vai chegando às raias do incontrastável.

Essa modificação de estrutura social, e suas implicações até na estrutura do direito, haveria de ter repercussões óbvias no plano das instituições políticas, isto é, no funcionamento dos órgãos permanentes que organizam o Estado e preservam a segurança da Sociedade: aqui, exatamente, o fulcro da crise do Estado de Direito. 
Quando o sonho do Estado Constitucional - visto ao prisma de elemento de equilíbrio entre os contrastes verificados no seio do próprio Estado começou a esmaecer, na virada do século XX, passou-se a enxergar o Estado de Direito em têrmos de direito administrativo: o Estado de Direito, prelecionaram Otto Meyer e Herrnritt, seria o que dispusesse de um bem ordenado direito administrativo, através do qual o exercício da Administração, em relação com os direitos subjetivos e os direitos privados dos cidadões, estivesse submetido a padrões legais e judiciários pré-determinados; assim, o Estado de Direito seria uma espécie de Estado de justiça Administrativa (Justizmässigkeit der Verwaltung: cfr. Grundlehren des Verwaltungsrechtes, de Herrnritt, Tübingen, Mohr, 1921, p. 37).

Mas a Administração foi inflando, no correr do século atual, e, com isso, cresceriam seu raio de ação e seus podêres: inflacionou-se, entretanto, a ordem regulamentar, que não se restringiria aos clássicos padrões do debulhamento das leis (as anciãs Rechtsverordnungen, dos tratadistas germânicos), pois exorbitaria nos desmesurados regulamentos de polícia (Polizeiverordnungen) ou nos igualmente amplos regulamentos administrativos (Verwaltungsverordnungen) (cfr. Fleiner, Institutione des Deutschen Verwaltungsrecht, Tübingen, Mohr, 1922, p. 75, et passim).

Êsse fato, quer dizer, o brotar caudaloso das leis materiais ao exterior da fonte do Poder Legislativo, aceleraria a crise do Estado Constitucional e, como vimos, do próprio Estado de Direito, mesmo que se pretenda, a um, do outro distinguir: em sua forma prisca, vigente da Era Liberal, os órgãos legiferantes não tiveram o dinamismo que lhes permitisse suprir a Administração dos instrumentos normativadores indispensáveis, em momento histórico no qual tanto se exige de sua ação.

Quanto mais tardígrado o Legislativo, mais o Executivo, a Administração, desenvolve suas emanações regulamentares, com isso gerando-se um círculo vicioso, onde o grande lesado é o direito subjetivo dos membros da cidadania.

No quadro do Estado contemporâneo não é mais a lei o único instrumento que obriga alguém a fazer ou deixar de fazer algo: e não o é, apesar da matéria ainda estar consignada na letra das declarações constitucionais de direitos e garantias individuais, como no caso do diploma brasileiro de 1967, embora outros - tal a Constituição francesa de 1958 - não a tenham consignado, nem emitido expressas declarações de direitos.

Fato contemporâneo é que o regulamento, no mais amplo sentido - a lei material, porque com feitio e fôrça de lei formal, embora não oriunda do Poder Legislativo, - também obriga o cidadão a fazer ou deixar de fazer... 
O Estado de Direito foi a quintessência do pensamento político que a filosofia do século XVIII construiu, e colocou sob o pálio da liberdade. Para Montesquieu, o nome dessa filosofia política oitocentista, a liberdade se definiria pelo exercício pleno da vontade do membro da sociedade humana, com tôda garantia e segurança: “(...) l'opinion où 1'on est que l'on exerce sa volonté"; “(...) cette tranquilité d'esprit qui provient de l'opinion que chacun a de sa sûreté".

Entretanto, como escreveu o professor Louis Trotabas, em seu Manuel de Droit Public et Administratif (Paris, L.G.D.J., 1964, p. 94), essa concepção de liberdade apresentava um sentido fundamentalmente negativo: "antes protege o indivíduo do que lhe atribui um poder positivo". O Estado de Direito, que haveria de ter circunscrito pela lei o exercício da Administração e dos Podêres do Estado, seria o instrumento de consumação do sentido positivo de liberdade.

Agora, é mister o encontro da fórmula que possibilite conciliação dos extravasamentos do Poder Executivo, com as exorbitâncias de seus podêres de polícia e regulamentares, e do tardigradismo do Poder Legislativo, sem o que fenecerá mesmo o Estado de Direito e a liberdade do cidadão.

Nos dias fluentes, duas tentativas formais hão de ser assinaladas, no sentido da busca de solução para a incompatibilidade entre a morosidade dos órgãos legiferantes e o dinamismo da Administração que tem resultado na apontada crise do Estado de Direito: uma reside na Constituição francesa de 4 de outubro de 1958; a outra, na Constituição brasileira de 24 de janeiro de 1967.

9. Por fôrça da obra dos filósofos políticos do século XVIII, e da Revolução de 1789, durante quase dois séculos o ideal do constitucionalismo assentou na especialização de cada um dos três podêres do Estado, e na atribuição do monopólio da fatura das leis ao Parlamento, Congresso, ou que outro nome tivesse o ramo legislativo. Pois foi exatamente na pátria daqueles filósofos, em França, onde se tentaria a primeira experiência para a ruptura da tradição de duzentos anos.

A Constituição que De Gaulle inspirou, em 1958, estatuiu uma classificação de leis que, em substância, implicou na outorga de competência legiferante também ao poder executivo.

Com efeito, pelo artigo 34, o diploma francês estatui que "a lei é votada pelo Parlamento", mas em disposições seguintes enuncia o restrito elenco do que haverá de ser objeto de "regras" fixadas na lei; tudo o que não foi especificado como matéria a normativar através de lei "tem um caráter 
regulamentar", segundo o preceituado no artigo 37. Nessas condições, a Constituição vigente em França inovou duas vêzes a tradição constitucional: $1 .^{\circ}$ - quando elencou, restritivamente, o que deve ser objeto de lei e seja, portanto, atribuível à competência do legislativo; $2 .^{\circ}$ - quando instituiu um conceito nôvo, ampliado, de regulamento.

A lei - na França atual - não é mais aquilo que Rousseau definia como expressão da vontade geral, emanada do Parlamento, que seria o colégio dos representantes do povo ou da nação; o domínio do regulamento compreende, hoje, tudo aquilo que não foi reservado ao domínio da lei. Segundo bem assinalou Trotabas (ob. cit., p. 241), na Constituição francesa de 1958 “a competência do legislador é definida por uma enumeração limitativa, enquanto que a do poder regulamentar é extensiva, incidindo sôbre tôdas as matérias que não são do domínio da lei" (os grifos são do mestre citado). Em outros têrmos, o poder do legislador gaulês coetâneo remanesce nalgumas ilhas de prerrogativas, isoladas no oceano das competências do executivo.

É evidente que a experiência encerrada no diploma de De Gaulle não contribui para a preservação do Estado de Direito, desde que simplesmente institucionaliza, formaliza, a exuberância regulamentar de um dos podêres, assim dando fôro, constitucionais ao que tanto ameaça aquela sonhada liberdade com segurança, do pensamento de Montesquieu. Sendo o poder regulamentar intrìnsecamente, inelutável e necessàriamente, discricionário, a experiência da Constituição francesa de 1958 apenas agrava os perigos do ressurgimento - no século XX - de um nôvo despotisme éclairé, em tudo semelhante àquele contra o qual tanto se pensou e sofreu na Europa dos séculos XVIII e XIX.

10. Parece que a Constituição brasileira, deliberada entre 1966 e janeiro de 1967, teve como inspiração inicial a obra referendada pelos franceses em 1958. Todavia, no curso da elaboração do projeto, e na sua votação, ela se transformaria em uma espécie de diploma eclético, retratador de certo compromisso entre o constitucionalismo clássico e um ideal ainda não precisado de constitucionalismo moderno. Por isso, lògicamente, o diploma de 24 de janeiro está longe de ser uma peça coerente em todo o seu conjunto: aqui se resguardam vitaliciedades (medievalismo autêntico...); ali se enuncia a independência de podêres (estamos com Montesquieu, em 1748: "on ne peut arrêter le pouvoir que par le pouvoir (...)”); mais adiante se derrama uma relação de direitos e garantias individuais que faria inveja aos redatores da Declaração de $1789 .$. 
Não obstante, num ponto acreditamos enxergar algo de efetivamente válido, que permite referir a Constituição brasileira como revolucionária: é na parte onde foi tratado "Do Processo Legislativo". Mas não sòmente entre aí; pois a novíssima Carta federal assenta no pressuposto de que a vida moderna destruiu a ficção da simetria interna da ordem legal, e de que a sociedade contemporânea é regida por leis de múltiplas fontes: assim, não elidiu as possibilidades de suplementação do sistema legal com as regras normativadoras emanadas de diversos centros sociais que buscam, por vias heterodoxas, o elemento coesivo compensador da competição das fôrças sociais (por exemplo: quando atribuiu aos sindicatos o exercício de funções delegadas de poder público, e quando possibilitou à Justiça do Trabalho a edição das normas e condições do trabalho, em ambos os casos tratando-se de legislar através de expedientes heterodoxos) como parcialmente já o fazia o diploma de 1946.

Na parte em que ordenou o processo legislativo, a Constituição de 1967 ensejou o incentivo do aceleramento da ação legiferante, pelo poder especializado. Os preceitos do artigo 54 e seus parágrafos, seguindo a tradição constitucional brasileira de participação do Executivo na confecção das leis (v. o art. 53 da Constituição imperial de 1824, e os comentários de URUGUAI. In: Ensaio sôbre o Direito Administrativo, I.N., ed. 1960, p. 33, e Pimenta Bueno. In: Direito Público Brasileiro e análise da Constituição do Império, I.N., 1958, p. 144), aperfeiçoou o processo, quando permitiu ao Presidente da República a fixação de certo prazo para deliberação da matéria, após cujo transcurso ela será tida como aprovada, e se transformará em lei. Nessas condições a recepção pelo direito público da velha regra segundo a qual "qui tacat, consentire videtur", possibilitou que o tardigradismo do Legislativo se corrija ou, então, que se legitime em têrmos de Estado de Direito a edição de leis pelo Poder Executivo.

É certo que o enunciado das várias categorias de leis formais, feitas pelo artigo 49 da Constituição novíssima, robustece a competência legiferante do Chefe do Executivo, em moldes não ortodoxos, como no caso das leis delegadas e dos decretos-leis. Mas não chega ao ponto de minimizar a função do Poder Legislativo, como fêz o similar diploma francês de 1958, ao reduzir a área da lei formal em detrimento da lei material do regulamento.

A Carta indígena de 1967 tem contra si as increpações dos tradicionalistas, que a encaram como um documento formalizador de virtual ditadura. Neste particular, entretanto, nós a louvamos com todo vigor: ela não é, certamente, uma obra de inspiração liberal, mas, a nosso ver, encerra - no decidido pelos constituintes - a única possível e democrática opção no quadro contemporâneo da crise do Estado de Direito. 
O Brasil foi regido, desde 1824, por múltiplas constituições que demonstramo-lo em nosso artigo acima citado, sôbre "As Constituições Brasileiras (...)", - se tornaram dessuetas, ao contraste das realidades sociais e políticas. E por isso a nação padeceu traumas, dos quais a democracia e a liberdade foram os mais lesados.

O Estado contemporâneo há de ser dinâmico, em sua ação como na feitura dos instrumentos jurídicos que a tal ação têm de reger; a ordem regulamentar, o poder de polícia, há de estar em dia com o problema social contingente: se o arsenal de leis (formais) se exaure, a ordem regulamentar (a lei material) supre-lhe a carência. Destarte, a aceleração do processo legislativo constitui a única opção idônea, democrática, para evitar que o Poder Administrativo, ancilar do Executivo, na observação do Visconde do Uruguai, supra com procedimento unilateral, pela ordem regulamentar, a exaustão do arsenal de leis.

Admitimos que a Constituição de 1967 não tenha restabelecido, em sua plenitude, o ideal do constitucionalismo democrático à maneira do século anterior. Mas, sê-lo-ia possível? A perplexidade dos juristas do Velho Continente, que antes mencionamos, apresentando suas elucubrações sôbre a crise (para alguns dêles "mortal") do Estado de Direito, responde por nós.

A confirmar a engenhosidade da fórmula adotada no Brasil para a aprovação tácita de proposições do Presidente da República, temos o fato do expediente idêntico, consagrado no artigo 156 da Constituição paraguaia promulgada em 25 de agôsto de 1967.

Argüir-se-á, eventualmente, que a imitação guarani não nos honrará, por tratar-se de um país sem tradição democrática.

Havemos de convir que, nessa matéria, nós, a exemplo da França, nossa fonte de inspiração política, não temos muito de que nos orgulhar... 